\title{
The Crime Victims' Rights Act: Rhetoric or reality?
}

\author{
Patricia L Sattler ${ }^{1}$ \\ 1 School of Social Welfare, University of Kansas, Lawrence, Kansas, USA
}

Received 31 March 2020

Accepted for publication 9 June 2020

Published 30 June 2020

\begin{abstract}
Crime victim's rights legislation including the Victim and Witness Protection Act of 1982 (VWPA) and the Crime Victims' Rights Act of 2004 (CVRA) brought attention to the plight of the crime victim and called on justice professionals and the public to recognize victims' value, worth, and role within a justice model that seeks to hold offenders accountable and increase public safety. The CVRA was the first federal policy to grant participatory rights to victims of crime; it served as a model statute for states enacting similar legislation. Beyond the eight participatory rights, implementation and administration of the CVRA is recommended but not required by law enforcement, prosecutors, or the judiciary. Instead, these justice professionals are encouraged to "make a good faith effort" in delivering these rights to victims of crime. This paper tells the story of the victims' rights movement before utilizing the Narrative Policy Framework to analyze the CVRA. Highlighting several key issues of relevance to the social work profession, a call to action is issued for social workers and policymakers to shift current narratives and more clearly define who constitutes a victim, how these rights are to be implemented and by whom, and to develop enforcement mechanisms.
\end{abstract}

Keywords: victims' rights; policy analysis; narrative policy framework; social work

The plight of crime victims has been well documented since the early 1960s (Doak, 2005) when the U.S. Crime Victims' Rights Movement was in its infancy. In the decades since, key state and federal victims' rights legislation has been enacted. None are more important than the Victim and Witness Protection Act of 1982 (VWPA) and the Crime Victims' Rights Act (CVRA) of 2004. Both the VWPA and CVRA grant federal crime victims important rights, such as the right to participate and be reasonably heard in criminal proceedings, the right to be treated with fairness and respect, and the right to proceedings free from unreasonable delay. The CVRA has also served as model legislation for states enacting similar victims' rights legislation nationwide, such as Arizona or Nebraska. However, the lack of adequate scope of the CVRA when defining a victim and the unclear operationalization of what it means to participate or be heard, suggest that victims' rights largely depend on the laws of the jurisdiction where the crime is perpetrated and how that jurisdiction conceptualizes victims or their rights.

This article begins with a brief review of the U.S. criminallegal system and evolution of the victims' right movement before examining the CRVA via a narrative policy framework.
While most of the extant literature on victims' rights and the CVRA is situated in legal scholarship, this policy analysis fills an important gap by bringing a social work perspective to the conversation and argues for a more prominent social work role in addressing victims' rights.

\section{Crime and victimization}

In 2018, the Federal Bureau of Investigation (FBI) recorded 1,206,836 violent crimes (e.g. robbery, homicide, aggravated assault and rape) committed nationwide; violent offenses fell by 0.4 to $12 \%$ in all categories except rape which increased by nearly 3\% over 2017 estimates (FBI, 2019). These figures reflect only those crimes reported to law enforcement agencies who voluntarily participate in the FBI's Uniform Crime Reporting (UCR) program.

Although it is difficult to adequately capture the specific number of individuals directly and indirectly affected by violent crime in the U.S., over 6.3 million individuals 12 years of age and older reported experiencing a violent victimization in the 2018 National Crime Victimization Survey (NCVS), an increase of $13 \%$ over 2017 estimates. The number of rapes or sexual assault victimizations grew by nearly $85 \%$ while 
robberies fell by roughly 7\% from 2017 to 2018 estimates (Morgan and Oudekerk, 2019). Non-violent offenses such as property crimes totalled 7,196,045 criminal cases annually in 2018 (FBI, 2019); in 2018 approximately 13.5 million household victimizations due to property crimes are reported in the NCVS (Morgan and Oudekerk, 2019). While roughly 9 million criminal cases were recorded by law enforcement for violent and non-violent offenses in 2018 (FBI, 2019), nearly 20 million U.S. residents reported experiencing physical, emotional, or financial harm as a direct result of the commission of a crime in 2018 (Morgan and Oudekerk, 2019). It is well established that not all crime is reported to law enforcement making it difficult, if not impossible, to understand the totality of crime and victimization in the U.S. (Eikenberry, 1987; Herrington, 1987; Strang, 2002; Young and Stein, 2004). This is evidenced in the disparities between FBI UCR and NCVS data. Depending on the data set utilized, one can paint vastly different narratives about the impacts of crime and victimization on individuals, families and communities.

\section{Evolution of victims' rights}

With no formalized legal framework established in the U.S. prior to the American Revolution which began in 1775, crime victims were often responsible for the prosecution of their own criminal cases (Boland and Butler, 2009; Chapin, 2010). As criminal law became more structured and systematized, the modern day criminal-legal system and the public prosecution model were borne (Friedman, 1994). Over time this system has evolved into an adversarial, antagonistic and confrontational bramble for victims, offenders and the state. It was, and in many ways remains "a results based, winlose system" (Wilson, 2014, p. 154) where the rights of the defendant, and interests of the larger society, appear paramount (Robinson and Dubber, 2007). The victim, forgotten (Roland, 1989), was but an appendage in a system appallingly out of balance (President's Task Force, 1982).

From the American Revolution until the early 20th century, victims of crime had little to no influence to participate in the criminal adjudicatory process unless they appeared as witnesses at the criminal trial (Chapin, 2010; Kelly, 1983), in which case the involvement of victims was purely evidentiary. Beyond that, little was asked of or acknowledged about the victim; their perceptions or experience were rarely solicited (Kelly, 1983; Strang, 2002). Victims of crime, in other words, had little, if any, value in the criminal-legal system (Eikenberry, 1987; Giannini, 2010; Kyl, Twist and Higgins, 2005; Waller, 2011; Wilson, 2014). By the 1960s, crime victims, mostly women and victims of sexual assault or intimate partner violence, were growing increasingly dissatisfied with their overt exclusion from criminaladjudicatory processes. Seeking recognition and acknowledgement in the criminal-legal system (Karmen, 2012), the modern crime victims' rights movement was born in the $1970 \mathrm{~s}$.

Gradually, the victims' rights movement gained strength in numbers, influence and political standing. From the women's movement to the civil rights movement and beyond, grassroots advocacy worked to promote the role and recognition of the victim (Kyl et al., 2005; Levine, 2010; Young and Stein, 2004). In 1965, California became the first state in the country to establish a victims' compensation program, the state of New York soon followed (Young and Stein, 2004). By 1979, 28 states had established victims' compensations programs (Young and Stein, 2004). In 1972, the first rape crisis centers and victim assistance programs were established in Berkeley, CA and Washington, D.C. (Karmen, 2012). In the same year, the first NCVS uncovered a situation much more challenging than previously understood: crime and victimization rates were higher than law enforcement data suggested (Boland and Butler, 2009; Young and Stein, 2004) and the toll on victims was tremendous (Boland and Butler, 2009). By 1974, several developments were underway. The first victim impact statement was created in Fresno County, CA (Adams and Osborne, 2001), while the first organization to provide support for survivors of homicide victims was organized in Washington State (Young and Stein, 2004). Further, three demonstration projects to provide better notification to and support of victims and witnesses were funded by the Federal Law Enforcement Assistance Administration (Young and Stein, 2004).

As the victim's rights movement progressed and momentum increased throughout the late 1970s and early 1980s, the focus would shift from victim services and assistance to the treatment of victims from their first contact with law enforcement through the adjudication of the criminal act (Boland and Butler, 2009; Karmen, 2012). Wisconsin became the first state to pass a Victims' Bill of Rights in 1980 (Young and Stein, 2004). In 1982, California would codify the first victims' rights amendment; by 2002, 32 states would have similar victims' right amendments (Adams and Osborne, $2001)$ in their state constitutions. It would be another 16 years before four additional states would adopt state constitutional amendments on victims' rights (National Victims' Constitutional Amendment, n.d.).

Historically, crime victims who engaged with the criminallegal system experienced a secondary victimization (Campbell and Raja, 1999; Orth, 2002; Patterson, 2011) as soon as or shortly after they reported their experience to law 
enforcement (Boland and Butler, 2009; Herrington, 1987; Waller, 2011; Wilson, 2014). Literature reports insensitive and unresponsive police force and prosecutors, as well as aggressive defence attorneys and judges who have not always empathized with victims of crime (Herrington, 1987; Waller, 2011; Wilson, 2014). Herrington (1987) and Boland and Butler (2009) report victims' requests for information and supported went unanswered; they were forgotten about in a "justice system that was indifferent to their most basic needs" (Young and Stein, 2004, p. 3). This secondary victimization led to a confluence of events, namely victims' refusal to cooperate with law enforcement and prosecuting attorneys in the reporting and prosecution of crime (Goldstein, 1982; Herrington, 1987; A. Roberts and Springer, 2007; Young and Stein, 2004).

In truth, without victim involvement there is little the criminal-legal system can do to enhance public safety. Law enforcement is unable to identify the commission of many crimes without victims first reporting the harms they experience (Hagan, 1983). If victims do not report crime to law enforcement, prosecutors do not have cases to bring forward and judges cannot hold offenders accountable or address community safety concerns. Without victim engagement, the criminal-legal system cannot and does not function as intended (Herrington, 1987).

In 1982, then-President Ronald Reagan established the President's Task Force on Victims of Crime to address the treatment and re-traumatization of crime victims in America (Adams and Osborne, 2001; Eikenberry, 1987; Levine, 2010). Chaired by California attorney, Lois Herrington, the task force held public hearings around the country and later presented their findings in a report provided the President (Adams and Osborne, 2001; Eikenberry, 1987; Levine, 2010). This report highlighted the victims' role and status in the criminal-legal system and presented 68 recommendations to improve services and crime victim support (Boland and Butler, 2009; Young and Stein, 2004). The Task Force's work was central to the development of several critical victims' focused initiatives including federal legislation that led to the enactment of the Victims of Crime Act (VOCA) of 1984 which established the Crime Victims Fund (Boland and Butler, 2009; Young and Stein, 2004). By 1986, VOCA funds were being distributed to states for victim assistance programming (Boland and Butler, 2009), justice professionals were being trained, and standards for victim assistance programs were established (Young and Stein, 2004). After 34 years, VOCA funds are still supporting the work of victim assistance programs nationwide (U.S. Office of Justice Programs, 2017) although limited evidence exists regarding program implementation or effectiveness.
Simultaneous to the work of the President's Task Force in 1982, the Federal Victim and Witness Protection Act was drafted that same year with the expressed intent to ensure victims' rights in the states (Young and Stein, 2004). This legislation signalled the first step towards federal recognition of crime victims everywhere (Young and Stein, 2004).

\section{Victim and Witness Protection Act of 1982}

The Victim and Witness Protection Act (VWPA) of 1982 (Pub. L. No. 97-291) was the first piece of victims' rights legislation that recognized the important and perhaps critical role that crime victims play in the U.S. criminal-legal system (Levine, 2010). The section 'key findings and purposes' in the VWPA (1982) acknowledged the physical, psychological and financial harms experienced by victims both as a result of the criminal act and of their engagement with the criminal-legal system. Additionally, the VWPA (1982) recognized that while the offender has a constitutional right to legal counsel who explains both the criminal-legal processes and offenders' rights, no such right or service exists for crime victims. Further, the VWPA (1982) sought to ensure that the federal government did everything within its power and available resources "to assist victims and witnesses of crime without infringing upon the constitutional rights of the offender" ( $p$. 1249).

The most important piece of the Act, Federal Guidelines for Fair Treatment of Crime Victims and Witnesses in the Criminal-legal System, features in the last two pages. Consistent with the purposes of the VWPA (1982), the U.S. Attorney General needed to prepare guidelines on the treatment of federal victims and witnesses for the Department of Justice staff. In the Act, law enforcement was tasked with ensuring victims received, as soon as possible, information regarding the criminal-legal system and their role in the criminal adjudicatory process as well as information about medical and social services available. Additionally, law enforcement's responsibility was to provide information on the availability of crime victims' compensation and community-based programs to victims encountered in their jurisdiction (Victim and Witness Protection Act, 1982). According to the VWPA, victims of major serious crimes, their families, as well as witnesses were entitled to receive, after providing their contact information to what is identified as the appropriate official, "prompt advance notification, if possible, of judicial proceedings relating to their case" (Victim and Witness Protection Act, 1982, p. 1256). Similarly, victims and witnesses were entitled to information on how justice professionals could protect them from intimidation (Victim and Witness Protection Act, 1982). 
Aside from the clearly enumerated responsibilities of law enforcement set forth in this Act, the responsible actors who should notify victims on the availability of protection, of scheduling changes, or of other judicial proceedings remained unclear (Victim and Witness Protection Act, 1982). Equally, the characteristics of a victim were uncertain, and the Act did not offer a description. While the VWPA acknowledged the presence of the victim in the criminal-legal system, it would be another 22 years before victims would move from passive to more active roles and be granted participatory rights (Levine, 2010).

\section{The Crime Victims' Right Act of 2004}

While the Victim and Witness Protection Act of 1982 brought fair treatment standards to federal victims and witnesses, it did not go far enough. Fair treatment of crime victims under the VWPA was more a suggestion than a right. The Crime Victims' Rights Act (CVRA) of 2004 (18 U.S.C. § 3771(a)), part of the larger Justice for All Act of 2004, Pub. L. No. 108-405, 118 Stat. 2260, attempted to remedy this by providing federal crime victims significantly expanded rights. Further, the CVRA provided mechanisms, at the federal level, for the enforcement of crime victims' rights (Crime Victims' Rights Act, 2004). Under the CVRA, federal victims, as well as prosecutors, were granted the legal standing necessary to assert such rights (Crime Victims' Rights Act, 2004).

Who is considered a victim? A crime victim, under the CVRA (2004) is a "person directly and proximately harmed as a result of the commission of a Federal offense or an offense in the District of Columbia" (Blondel, 2008, p. 258). In situations where the crime victim is 18 years of age or younger, or when the crime victim is otherwise unable to assert their rights due to incompetence, incapacitation or death, the victim's rights transfer to his or her legal guardian, family members or any other person so appointed by the courts.

The eight participatory rights enumerated under the CVRA (2004) include such rights as "the right to reasonable, accurate, and timely notice of any public court proceeding, or any parole proceeding, involving the crime or of any release or escape of the accused" (section 3771(a)(2) and the right to be treated with dignity and respect (section 3771(a)(8)). Additionally, crime victims have "the right to be reasonably heard at any public proceeding in the district court involving release, plea, sentencing, or parole" (Crime Victims' Rights Act, 2004, section 3771(a)(4)). Prior to this, victims had a right to be heard in limited circumstances only. The CVRA (2004) further grants federal crime victims the right to be present at any proceedings in which the crime(s) perpetrated against them are being litigated. These particular rights are important in the larger context of how the CVRA came to pass and how it helped shape state victims' rights statutes.

\section{Defining State's victims' rights}

While most state victims' rights statutes are modelled after the CVRA (2004), there is no consistency across states or a universal definition of a victim of crime. That is, a crime victim in Nebraska is defined differently than a crime victim in Arizona, while their rights may be similar, they are still different. For example, in Arizona "victim" is defined as "any person against whom a crime is committed" (Arizona Victims" Bill of Rights, n.d.; Arizona Victims' Rights Laws, n.d.). Contrarily, only "persons victimized by specific crimes as defined by law" meet the definition of a crime victim in Nebraska (Nebraska Victims' Rights Laws, n.d). In Arizona, a victim has the right to refuse an interview (Arizona Victims' Rights Laws, n.d.); no such right exists in Nebraska (Nebraska Victims' Rights Laws, n.d). A crime victim is Nebraska does not have the right to read pre-sentence reports in their cases or any standing to invoke their rights (Nebraska Victims' Rights Laws, n.d.) while a victim in Arizona has both (Arizona Victims' Rights Laws, n.d). The pre-sentence report takes a number of bio-psycho-social factors into consideration and is an important document used by the judiciary to determine the most appropriate sentence for an offender. Victims in Nebraska are deprived from important contextual information that could help them comprehend a judge's sentencing order for a particular offender. Finally, without standing to invoke their rights, the implication is that Nebraska's crime victims are not interested stakeholders.

Beyond the inconsistent definitions on who constitutes a victim and what rights are available, there are glaring disparities between the CVRA and state level statutes regarding who is responsible for delivering victims' rights or how and when they should be delivered. Limited empirical evidence exists outside of legal scholarship and opinion on the efficacy of victims' rights statutes, federal or otherwise. Much has been written about the prominence of victims' rights in legal statutes worldwide. There is a paucity of literature, however, regarding implementation of victims' rights policies or their effectiveness at increasing participation in criminal adjudicatory processes or mitigating the risk of secondary victimization. Both of these issues have been and continue to be central to the U.S. victims' rights movement. To address this gap, the CVRA is analyzed here utilizing a narrative policy framework.

\section{Narrative Policy Framework}

The Narrative Policy Framework (NPF) asserts its importance by providing a systematic method to examine the 
influence of policy narratives on the policy process, designs and outcomes (McBeth et al., 2014). Like all good storytelling, certain elements help tell a policy story such as setting, characters, plot and the moral (Sabatier and Weible, 2014; Stone, 2012).

Recent NPF scholarship argues that policy narratives must include at least one character and promote a solution or morale of the story (Lawton and Rudd, 2014; Sabatier and Weible, 2014; Stone, 2012). The setting is where the story unfolds (Sabatier and Weible, 2014), it is central to the developing narrative. Whether examining stories or policy narratives, there are always protagonists, antagonists and supporting characters (Sabatier and Weible, 2014; Stone, 2012). These characters typically include heroes or heroines, "innocent" victims and villains (McBeth, Shanahan and Jones, 2005; Sabatier and Weible, 2014; Stone, 2012). Finally, while the plot tells readers the why of a story (Elements of Plot, n.d.), the moral of the story offers the solution (Sabatier and Weible, 2014; Stone, 2012).

\subsection{The story of the Crime Victims' Rights Act of 2004}

Behind the CVRA is a story of the advocacy efforts of the family members of Scott Campbell, Stephanie Roper, Wendy Preston, Louarna Gillis and Nila Lynn (Kyl et al., 2005). Scott Campbell was murdered in April 1982, his body never found (Drummond and Hicks, 1990). Campbell's parents were barred from the courtroom, never notified of appellate proceedings, and never informed of the pre-trial release of one of the defendants; they were silenced nearly every time it mattered, including at sentencing hearings for both defendants (Kyl et al., 2005). Stephanie Roper's parents heard details of her kidnapping and brutal rape and torture by two men, during early preliminary hearings (Meyer, 1982). They were also shut out of the courtroom during the trials of both defendants (Kyl et al., 2005). Wendy Preston was murdered in her parents' Florida home in 1977; her parents were told the State of Florida was the "victim" in the case and that they'd only receive notification if they were to be called as witnesses (Kyl et al., 2005). Louarna Gillis was murdered because she was the daughter of a Los Angeles Police Detective (John Gillis Biography, 2003). Louarna's father was removed from the courtroom prior to the start of the trial (Kyl et al., 2005) although the defendant's family was allowed in (John Gillis Biography, 2003). Nila Lyn was one of two women murdered at a homeowner's association meeting in Peoria, Arizona (Kyl et al., 2005). Nila's husband wanted the defendant to be sentenced to life without the possibility of parole but was deprived the option to contribute to the defendant's sentencing hearing; ultimately, the defendant received the death penalty (Kyl et al., 2005). Shut out of or silenced during the criminal proceedings in which the murders of their loved ones were being litigated, these family members, secondary victims in their own right, lobbied for decades for recognition, respect and voice in the criminal-legal system.

\section{Analysis and discussion}

The narrative surrounding victims' rights legislation conflates tragedy with suffering and designates some victims and their suffering as worthier than others; that is, the suffering of innocent victims (e.g. homicide victims) matters more than the suffering of those considered to be culpable in their own victimization (e.g. sexual assault victims). As Greer (2007) so eloquently articulates, "there exists a hierarchy of victimization which is reflected and reinforced in the media" (p. 22) and policy narratives. The amplification of the innocent victim's suffering not only garners massive media coverage and public attention, it compels, as Wood (2003) argues, immediate and particular responses from policymakers. One need only look at language contained in the 1982 President's Task Force on Victims of Crime Report to see how long the "innocent victim" narrative has persisted and how many statutes have been enacted in a specific victim's name (very rarely a racial or ethnic minority). No matter the case, the criminal-legal system has long focused on the assumption that crime victims should be seen and not heard (Twist, 2006), innocent or otherwise. The stories underpinning the victims' rights movement of the 1960s and 1970s as well as that of the CVRA vividly illuminate these narratives.

In their concern for alleviating victims' suffering, victims' rights advocates and policymakers have failed to consider the practical implications of their policy solutions (Blondel, 2008). In addition to federal crime victims' rights legislation, each state has passed numerous victims' rights statutes. Thirty-six states have constitutional amendments though victims are very often turned away from the courts, when trying to assert these rights (Boland and Butler, 2009). Unlike offenders' rights which are enshrined in the U.S. constitution and many state and federal legal statutes, the CVRA is, for all intents and purposes, a set of guidelines which federal prosecutors, judges and law enforcement are encouraged but not required to consider (Levine, 2010). Further, the CVRA provides little guidance on how best to incorporate the statute into practice (Blondel, 2008). This begs the question: are victims' rights truly a right, recommendation or rhetoric?

Kyl et al. (2005) asserts there has been limited success at the state and federal levels in securing meaningful, enforceable rights for crime victims. Perhaps this is due in part to a lack of understanding by the very justice professionals tasked with providing such rights (Goodrum, 2007). Perhaps it is due to the fact that terms such as "reasonable," "timely," 
"participation," "fairness" and "respect" are subjective and understood inconsistently across professions and jurisdictions; particularly when they've not been uniformly operationalized. Perhaps this is because "victim" and "right" are ambiguous, elusive, politically freighted and practically contested (Rock, 2014, p. 12). Unlike offenders clearly defined constitutional rights, victims' rights are dependent on how each state and local jurisdiction conceptualizes and applies them (Boland and Butler, 2009; Kyl et al., 2005). Further, victims' rights legislation contain few procedural guidelines and, unlike offender's rights, there are no consequences for noncompliance (Pugach and Tamir, 2017).

Perhaps the limited success of securing meaningful, enforceable rights for crime victims has something to do with the competing narrative on the rights of offenders. Victims' rights have historically been pitted against offender rights even when offenders' rights are not being threatened (Boland and Butler, 2009; Waller, 2011; Zappalà, 2010). This eitheror dichotomy is a narrative that has long persisted in the U.S. criminal-legal system. Although some victims' rights opponents argue that victim participation and voice is highly prejudicial to defendants (Wilson, 2014) because victims are emotional, retaliatory and vengeful (Guastello, 2005; Umbreit, 1989), little concrete evidence has been offered in support of such claims (Erez and July 1999; Hans, 2014). Karp and Warshaw (2006) found no difference in death penalty decisions when victims' families did or did not testify. Internationally, Roberts and Manikis (2011) found that sentencing practices are not harsher following the introduction of victim impact statements.

Another criticism of the CVRA is that victim participation, particularly the right to not be excluded and the right to be reasonably heard, may entail huge delays in speedy trial rights (Zappalà, 2010). Such criticism completely ignores the fact that the speedy trial clock is frequently tolled by defendants themselves. Yet another criticism of victims' rights legislation argues the presumption of innocence is violated because victims' participation in a criminal proceeding implies a crime was committed and someone was harmed (Zappalà, 2010). This criticism neglects to consider that perhaps it isn't the victim or their participation that implies a crime was committed but rather that criminal charges were filed and a trial is commenced. There appears to be no evidence that speedy trial rights are violated or that a victim's participation is unduly prejudicial to defendants.

Perhaps another reason for the limited rights for crime victims is related to the portrayal of crime and victimization in the media. Law and order has been romanticized by news and television programs (Waller, 2011). And the effects of crime and victimization have been reduced to television spots where the crime is committed, the offender apprehended, trial commenced and the victim saved, healed and restored in the span of 60 minutes or less. While these shows focus on saving victims, who have been portrayed as vulnerable, weak and innocent, such focus does not last long (Waller, 2011).

Finally, perhaps the lack of meaningful victims' rights is a result of the larger narrative that has historically framed the problem of the victim, their voice or their place in criminal adjudicatory processes. At the heart of the victims' rights movement is an ideal of equality whereby the scales of justice are more balanced through the equal distribution of rights $(\mathrm{Kyl}$ et al., 2005). Victims' rights advocates argue victims should have standing in the criminal-legal system equal to that of offenders' standing (Waller, 2011). Offenders' right advocates argue that elevating victims' rights places offenders' rights in peril (Guastello, 2005). Therein lies the paradox. Stone (2012) argues the paradox of equality or equal treatment looks different depending on which side you focus because equal treatment for one individual or group of individuals often means unequal treatment for the other. Perhaps the answer lies somewhere in between. Social workers are in a unique position to help navigate this paradox and are, in fact, called to do so in the profession's core values and purpose. Social work's mission and primary purpose is to enhance well-being and empower those who are vulnerable, marginalized and oppressed (NASW, n.d.). Empirical evidence demonstrates social and economic deprivation increases risk for victimization as well as criminogenic behavior (Green, 2007). The profession's commitment to social justice and recognizing the dignity and worth of every person mean social workers stand ready to move this conversation forward in ways that honor both victims and offenders. As is highlighted in the profession's ethical principles, "social workers strive to ensure access to needed information, services, and resources; equality of opportunity; and meaningful participation in decision-making for all people" (NASW, n.d.).

Shifting the narrative from equal distribution of rights to one focused on equity for all - victims, offenders and society - may help mitigate this. Cassell (1999) argues that victims' rights can build upon and improve the justice system by "retaining protection for the legitimate interests of prosecutors and defendants, while adding recognition of the equally powerful interests of crime victims" (p. 481). A justice that restores is one that ensures meaningful participation for all. Social workers have an important role in helping shift the winner take all narrative and facilitating a clear path forward for increasing victim participation without causing harm to defendants or offenders. The pursuit of justice need not be a zero-sum game. 


\section{Conclusion}

Examination of the narrative of the CVRA reveals that it was not designed to elevate the victims' status over that of defendants or the state. Crime victims are not even "accorded formal party status" (Boland and Butler, 2009, p. 6) under the CVRA. Having greater status than defendants or the state is pure conjecture. Victims are not privileged with decisionmaking authority; the right to confer with prosecutors does not obviate prosecutorial discretion and authority. Further, and drawing on this analysis, there is no narrative in the CVRA to suggest that elevating the rights of one group mean denying rights to the other group. Victims' desires to participate in the criminal-legal system are related to recognition, inclusion and an acknowledgment of the harms they've experienced by the state and offenders (Strang, 2002; Strang and Sherman, 2003).

For victims' rights legislation to be truly meaningful, victims must help conceptualize and clearly define what it means for them to participate in the criminal-legal system (Crawford and Goodey, 2000). Social workers can help facilitate these conversations by encouraging agency and voice while providing validation of and for victims' needs (Busch and Valentine, 2000). Central to empowerment focused practice, a cornerstone in social work training and education, is a focus on challenging the structural injustices that impact individuals and communities (Perkins and Zimmerman, 1995; Turner and Maschi, 2014). Policymakers must standardize victims' rights legislation nationwide and create enforcement mechanisms that hold justice professionals accountable in the same way they are held accountable for upholding offenders' rights (Crawford and Goodey, 2000). Social workers can help define this accountability in a way that facilitates equity and models the importance of fair treatment standards.

For victims' rights legislation to be truly meaningful, a victim in Nebraska should be guaranteed the same rights, recognition, and treatment as a victim in Arizona or Michigan. Social workers have a role in helping shape and implement such policies while advocating for a more balanced and equitable government investment in victims' services. Over the last three decades, large sums of money have been spent on building the prison industrial complex while little has been invested in services for crime victims (Roberts and Springer, 2007; Waller, 2011). As resource developers and brokers, educators and advocates, social workers are trained to respond to these issues and more across system levels (Patterson, 2012).

Finally, social workers must help re-conceptualize what it means to balance the rights of offenders with the rights of victims and the rights of society at large (Herrington, 1987). A "new paradigm of justice is required to transform the values and jurisprudence of criminal justice to include victims as stakeholders equal to offenders and the community" (Strang and Sherman, 2003, p. 25). It is incumbent upon social work to advance new justice narratives; narratives that reject the false dichotomy that pits victims' rights against offenders' rights and honors the dignity, worth and voice of all.

\section{References}

Adams, A. and Osborne, D. (2001) 'Victims' rights and services: A historical perspective and goals for the twenty-first century', McGeorge Law Review, 33(4), pp. 673-688.

Arizona Victims' Bill of Rights (no date) Available at: https://www.azleg.gov/const/2/2_1.htm (Accessed 6 June 2020).

Arizona Victims' Rights Laws (no date) Available at: https://law.lclark.edu/live/files/4917-arizona (Accessed 6 June 2020).

Blondel, E. C. (2008) 'Victims' rights in an adversary system', Duke Law Journal, 58(2), pp. 237-274.

Boland, M. L. and Butler, R. (2009) 'Crime victim's rights: From illusion to reality', Criminal Justice, 24(1), pp. 4-11.

Busch, N. B. and Valentine, N. (2000) 'Empowerment practice: A focus on battered women', Affilia, 15(1), pp. 8295.

Campbell, R. and Raja, S. (1999) 'Secondary victimization of rape victims: Insights from mental health professionals who treat survivors of violence', Violence and Victims, 14(3), pp. 261-275.

Cassell, P. (1999) 'Barbarians at the gates: A reply to the critics of the victims' rights amendment', Utah Law Review, 2(2), pp. 479-544.

Chapin, B. (2010) Criminal justice in colonial America, 16061660. Athens, GA: University of Georgia Press.

Crawford, A. and Goodey, J. (ed) (2000) Integrating a victim perspective within criminal justice: International debates. Vol. 3. Burlington, VT: Ashgate Publishing Company.

Crime Victims' Rights Act (2004) Available at: https://www.law.cornell.edu/uscode/text/18/3771 (Accessed 6 June 2020).

Doak, J. (2005) 'Victims' rights in criminal trials: Prospects for participation', Journal of Law and Society, 32(2), pp. 294-316. Eikenberry, K. (1987). 'Victims of crime/Victims of justice', Wayne Law Review, 34(1), pp. 29-49.

Elements of Plot Development (n.d.). Available at: https://thewritepractice.com/plot/ (Accessed 6 June 2020).

Erez, E. (1999) 'Who's afraid of the big bad victim? Victim impact statements as victim empowerment and enhancement of justice', Criminal Law Review, (July), pp. 545-556. 
Federal Bureau of Investigation (2019, September 30) FBI releases 2018 Crime Statistics. Available at: https://www.fbi.gov/news/pressrel/press-releases/fbireleases-2018-crime-statistics (Accessed 6 June 2020).

Friedman, L. (1994) Crime and punishment in American history. New York: Basic Books.

Giannini, M. M. (2010) 'Redeeming an empty promise: Procedural justice, the Crime Victims 'Rights Act, and the victim's right to be reasonably protected from the accused', Tennessee Law Review, 78(1), pp. 47-104.

Goldstein, A. S. (1982) 'Defining the role of the victim in criminal prosecution', Mississippi Law Journal, 52(3), pp. 515-561.

Goodrum, S. (2007) 'Victims' rights, victims' expectations, and law enforcement workers' constraints in cases of murder', Law and Social Inquiry, 32(3), pp. 725-757.

Green, S. (2007) 'Crime, victimization and vulnerability' in Walklate, S. (ed) Handbook of victims and victimology. Portland, OR: Willan Publishing, pp. 91-117.

Greer, C. (2007) 'News media, victims and crime' in Davies, P., Francis, C. and Greer, C. (eds.) Victims, crime and society: An introduction. London: Sage Publishing, pp. 48-65.

Guastello, C. (2005) 'Victim impact statements: Institutionalized revenge', Arizona State Law Journal, 37(4), pp. 1321-1340.

Hagan, J. (1983). Victims before the law: The organizational domination of criminal law. Toronto: Butterworths.

Hans, V. P. (2014) 'The impact of victim participation in Saiban-in trials in Japan: Insights from the American jury experience', International Journal of Law, Crime and Justice, 42(2), pp. 103-116.

Herrington, L. (1987) 'Victim rights and criminal justice reform', The ANNALS of the American Academy of Political and Social Science, 494, pp. 139-144.

John Gillis Biography and Interview (n.d.). Available at: http://vroh.uakron.edu/summaries/Gillis.php (Accessed 6 June 2020).

Karmen, A. (2012) Crime victims: An introduction to victimology. Belmont, CA: Wadsworth Cengage Learning.

Karp, D. R. and Warshaw, J. B. (2006) 'Their day in court: The role of murder victims' families in capital juror decision making' in Acker, J. and Karp, D. (eds.) Wounds That Do Not Bind: Victim-Based Perspectives On The Death Penalty. Durham, N.C.: Carolina Academic Press, pp. 275-295.

Kelly, D. P. (1983) 'Victims' perceptions of criminal justice', Pepperdine Law Review, 11(5), pp. 15-22.

Kyl, J., Twist, S. J. and Higgins, S. (2005) 'On the wings of their angels: The Scott Campbell, Stephanie Roper, Wendy Preston, Louarna Gillis, and Nila Lynn Crime Victims' Rights Act', Lewis and Clark Law Review, 9(3), pp. 581-628.
Lawton, R. N. and Rudd, M. A. (2014) 'A narrative policy approach to environmental conservation', Ambio, 43(7), pp. 849-857.

Levine, D. (2010) 'Public wrongs and private rights: Limiting the victim's role in a system of public prosecution', Northwestern University Law Review, 104(1), pp. 335-361.

McBeth, M. K., Jones, M. D. and Shanahan, E. A. (2014) 'The Narrative Policy Framework' in Sabatier, P.A. and Weible, C. M. (eds.), Theories of the policy process (3rd ed.). Boulder, CO: Westview Press. pp. 173-213.

McBeth, M. K., Shanahan, E. A. and Jones, M. D. (2005) 'The science of storytelling: Measuring policy beliefs in Greater Yellowstone', Society and Natural Resources, 18(5), pp. 413429.

Meyer, E. (1982) 'Family Hears Witnesses Tell of Coed's Brutal Rape, Murder' The Washington Post, 11 May. Available at: https://www.washingtonpost.com/archive/local/1982/05/11/f amily-hears-witnesses-tell-of-coeds-brutal-rapemurder/810e4483-26c1-4322-93fd-25d411c97c2c/

(Accessed: 6 June 2020).

Morgan, R. E., and Oudekerk, B. A. (2019) Criminal Victimization, 2018. Washington, D.C.:U.S. Department of Justice, Office of Justice Programs, Bureau of Justice Statistics. Available at: https://www.bjs.gov/content/pub/pdf/cv18.pdf (Accessed: 6 June 2020).

National Association of Social Workers (NASW). (no date) Code of Ethics. Available at: https://www.socialworkers.org/About/Ethics/Code-ofEthics/Code-of-Ethics-English (Accessed 17 June 2020).

National Victims' Constitutional Amendment Passage. (no date) Victims' Rights amendment adopted in three more states. Available at: http://www.nvcap.org/(Accessed 6 June 2020). Nebraska Victims' Rights Laws. (no date). Available at: https://law.lclark.edu/live/files/4961-nebraska (Accessed: 6 June 2020).

Orth, U. (2002) 'Secondary victimization of crime victims by criminal proceedings', Social Justice Research, 15(4), pp. 313325.

Patterson, D. (2011) 'The linkage between secondary victimization by law enforcement and rape case outcomes', Journal of Interpersonal Violence, 26(2), pp. 328-347.

Patterson, G. T. (2012) Social work practice in the criminal justice system. London: Routledge.

Perkins, D. D. and Zimmerman, M. A. (1995) 'Empowerment theory, research, and application', American Journal of Community Psychology, 23(5), pp. 569-579.

President's Task Force on Victims of Crime (1982) Final Report of the President's Task Force on Victims of Crime. 
Available

https://www.ovc.gov/publications/presdntstskforcrprt/87299. pdf (Accessed: 6 June 2020).

Pugach, D. and Tamir, M. (2017) 'Nudging the criminal justice system into listening to crime victims in plea agreements', Hastings Women's Law Journal, 28(1), pp. 45-72.

Roberts, A. and Springer, D. (2007) Social work in juvenile and criminal justice settings. Springfield, IL: Charles C. Thomas Publisher.

Roberts, J. V. and Manikis, M. (2011) Victim personal statements: A review of empirical research. Report for the Commissioner for Victims and Witnesses in England and Wales, London. Available at: https://papers.ssrn.com/sol3/papers.cfm?abstract_id=303213 $\underline{8}$ (Accessed 6 June 2020).

Robinson, P. H. and Dubber, M. D. (2007) 'The American model penal code: A brief overview', New Criminal Law Review: In International and Interdisciplinary Journal, 10(3), pp. 319-341.

Rock, P. (2014) 'Victims' rights' in Vanfraechem, I., Pemberton, A. and Ndahinda, F. M. (eds), Justice for victims: Perspectives on rights, transition, and reconciliation. London: Routledge, pp. 11-31.

Roland, D. L. (1989) 'Progress in the victim reform movement: No longer the forgotten victim', Pepperdine Law Review, 17(1), pp. 35-58.

Sabatier, P. A. and Weible, C. M. (2014) Theories of the policy process (3rd ed.). Boulder, CO: Westview Press.

Stone, D. A. (2012) Policy paradox: The art of political decision making (3rd ed.). New York: W.W. Norton and Company.

Strang, H. (2002) Repair or revenge: Victims and restorative justice. Oxford: Clarendon Press.

Strang, H. and Sherman, L. W. (2003) 'Repairing the harm: Victims and restorative justice', Utah Law Review, 1, pp. 1542 .

Turner, S. G. and Maschi, T. M. (2014) 'Feminist and empowerment theory and social work practice', Journal of Social Work Practice, 29(2), pp. 151-162.

Twist, S. J. (2006) 'Kenna v. District Court', Federal Sentencing Reporter, 19(1), pp. 30-35.

Umbreit, M. S. (1989) 'Crime victims seeking fairness, not revenge: Toward restorative justice', Federal Probation, 53(3), pp. 52-57.

U.S. Office of Justice Programs, Office for Victims of Crime.

(2017) Crime Victims Fund. Available at: https://ojp.gov/ovc/about/victimsfund.html (Accessed: 6 June 2020)

Victim and Witness Protection Act of 1982, Pub. L. No. 97291, 96 Stat. 1248 (1982) Available at:
https://www.govinfo.gov/content/pkg/STATUTE-

96/pdf/STATUTE-96-Pg1248.pdf\#page=6 (Accessed 6 June 2020).

Waller, I. (2011) Rebalancing justice: Rights for victims of crime. Lanham, MD: Rowman and Littlefied Publishers, Inc. Wilson, L. A. (2014) 'Rights of victims vs the rights of the accused: Striking a balance between the rights of victims and accused persons in the international criminal justice setting', University of Western Australia Law Review, 38(2), pp. 152174.

Wood, J. K. (2003) 'Justice as therapy: The victim rights clarification act', Communication Quarterly, 51(3), pp. 296311.

Young, M. and Stein, J. (2004). 'The History of the Crime Victims' Movement in the United States', National Organization for Victim Assistance. Available at: http://www.ojp.usdoj.gov/ ovc/ncvrw/2005/pg4c.html (Accessed: 6 June 2020.

Zappalà, S. (2010) 'The rights of victims v. the rights of the accused', Journal of International Criminal Justice, 8(1), pp. 137-164. 